Jekaterina Dofková

\title{
Českoslovenští architekti v SSSR
}

Klíčová slova: Antonín Urban; František Sammer; Jaromír Krejcar; Josef Špalek.

Kontakt: archpost@post.cz

Školitel: Vladimír Šlapeta

Tematický okruh: Architektura

\section{Czechoslovak Architects in the USSR}

The paper focuses on the activity of Czechoslovak architects in the USSR in the 1930s. For many decades, this topic has been obscured by ideology. In his article entitled "In Search for the Unrealized Heritage", architecture historian Selim Khan-Magomedov observes that there is a lack of accurate information about joint Czech-Russian projects. Works by many Czech architects have not been preserved in Russian archives. This is confirmed by František Sammer, a Czech architect who made a trip to the USSR between 1933 and 1937. 
Příspěvek se věnuje činnosti československých architektů v SSSR ve třicátých letech 20. století. Toto téma bylo po mnoho desetiletí zahaleno závojem ideologií. Historik architektury Selim Chan-Magomědov ve svém článku „Hledání nerealizovaného dědictví“ konstatuje, že přesných informací o společných česko-ruských projektech se nedostává. Práce mnoha českých architektů se v ruských archivech nezachovaly. Potvrzuje to i český architekt František Sammer, jenž v letech 1933 až 1937 absolvoval cestu do SSSR.

Ani v současnosti není vyhledávání informací týkajících se daného tématu jednoduché. Mezi českými badateli v oboru dějin mezinárodní moderní a soudobé architektury patří význačné místo profesoru Vladimíru Šlapetovi, jenž se věnuje tématu působení českých architektů v SSSR.

Materiály, jež se nacházejí v ruských archivech, nejsou digitálně zpracovány, a tím se neustále prodlužuje doba vyřizování vědeckých požadavků. Avšak ukončení doby socialismu zpřístupnilo řadu dalších, dosud zakázaných dokumentů použitých i pro danou práci.

Zajímavé jsou výsledky práce současných ruských vědců věnujících se osudu evropských specialistů v SSSR ve 30. letech. Např́iklad články a knihy M. Meeroviče, D. Chmelnického, E. Konyševové, kteří ve svých příspěvcích popisují každodenní život Bauhausu v SSSR v období prvních pětiletek.

Př́íspěvek „Českoslovenští architekti v SSSR“ mapuje současně dostupné fakty spojené s působením českých architektů v Rusku v návaznosti na jejich vlastní motivaci, která vedla k rozhodnutí opustit Evropu.

Práce se zabývá rekonstrukcí osudu československých architektů, objevuje jejich teoretický a praktický přínos sovětské architektuře. Příspěvek se omezuje na několik nejvýznamnějších osobností. Byli to: Antonín Urban, František Sammer, Jaromír Krejcar, Josef Špalek.

\section{ZKRÁCENÝ SOUPIS ZDROJU゚}

ALONI, Yael. Arieh Sharon: Architectural Competition - Second Prize. Boys and Girls' School, City of Louny - 1929. [online]. [cit. 2015-05-23]. Dostupné z: http://www.ariehsharon.org/Archive/Bauhaus-and-Berlin/Girls-School-City-of-Louny/16780562_vVMj3R\#! i=1265978667\&k=4dBWbks

BARKHIN, Mikhail. Mastera sovetskoy arkhitektury ob arkhitekture: Izbrannyye otryvki iz pisem, statey, vystupleniy i traktatov $v d v u k h$ tomakh. Moskva: Iskusstvo, 1975.

DOBRÁ, Hana. František Sammer a jeho blízcí. Plzeň: Archiv města Plzně, 1998. 
GINZBURG, Moisey. Arkhitektura sanatoriya Narkomata tyazheloy promyshlennosti v Kislovodske. Moskva: Akademiya Arkhitektury SSSR, 1940.

HONZÍK, Karel. Ze života avantgardy: zážitky architektovy. 1. vyd. Praha: Československý spisovatel, 1963.

CHERKASSKIY, I. Ye. Arkhitekturnoye oformleniye i otdelka metro. Stroitel'stvo Moskvy. 1935, : 8-39.

KAZUS‘, I. Sovetskaya arkhitektura 1920-kh godov: organizatsiya proyektirovaniya. Moskva: Progress-Traditsiya, 2009. ISBN 58-982-6291-1.

\section{FOTOGRAFIE}

[1] CAPITEL. Mikhael Zibenbrodt, Baukhauz-arkhiv, Berlin, Germaniya. [fotografie]. Soutěžní návrh na Palác sovětů v Moskvě. Antonín Urban, Philipp Tolziner, Tibor Weiner a Hannes Meyer. [online]. St. Petersburg: Capitel, 2011, 2011-03-28 [cit. 2014-03-09]. Dostupné z: http://www.kapitel-spb.ru/index.php/events/18-archive/49-zibenbrodt?showall=1

[2] ZABELLO, S. Ya. Metro Kirovskaja. Nikolaj Kolli, František Sammer. [fotografie]. Raboty arkhitekturnykh masterskikh. Díl 2: Otdel proyektirovaniya Mossoveta. 1936. pp. 18-19

[3] OGIBIN, Ludmila Ivanovna Konstantinova-Urban. [Fotografie]. Igor. Istoriko-kul'turnyi atlas goroda Ukhty.: Pervyye arkhitektory Ukhty. Ukhta, 2009. Dostupné z: http://atlas.ukhta-lib.ru

[4] PÜSCHEL, Konrad. Antonín Urban. [fotografie]. Buhaus-Universität Weimar. [online]. Dostupné z: https://e-pub.uni-weimar.de/opus4/frontdoor/index/index/docId/878

[5] GINZBURG, Moisey. Medicinské centrum sanatoria Ordžonikidze - Jaromír Krejcar a Josef Špalek. [fotografie]. Arkhitektura sanatoriya Narkomata tyazheloy promyshlennosti v Kislovodske. Moskva: Akademiya Arkhitektury SSSR, 1940, pp. 55-57.

[6] ZABELLO, S. Ya. Metro Kirovskaja. Nikolaj Kolli, František Sammer. [fotografie]. Raboty arkhitekturnykh masterskikh. Díl 2: Otdel proyektirovaniya Mossoveta. 1936. pp. 16-19. 

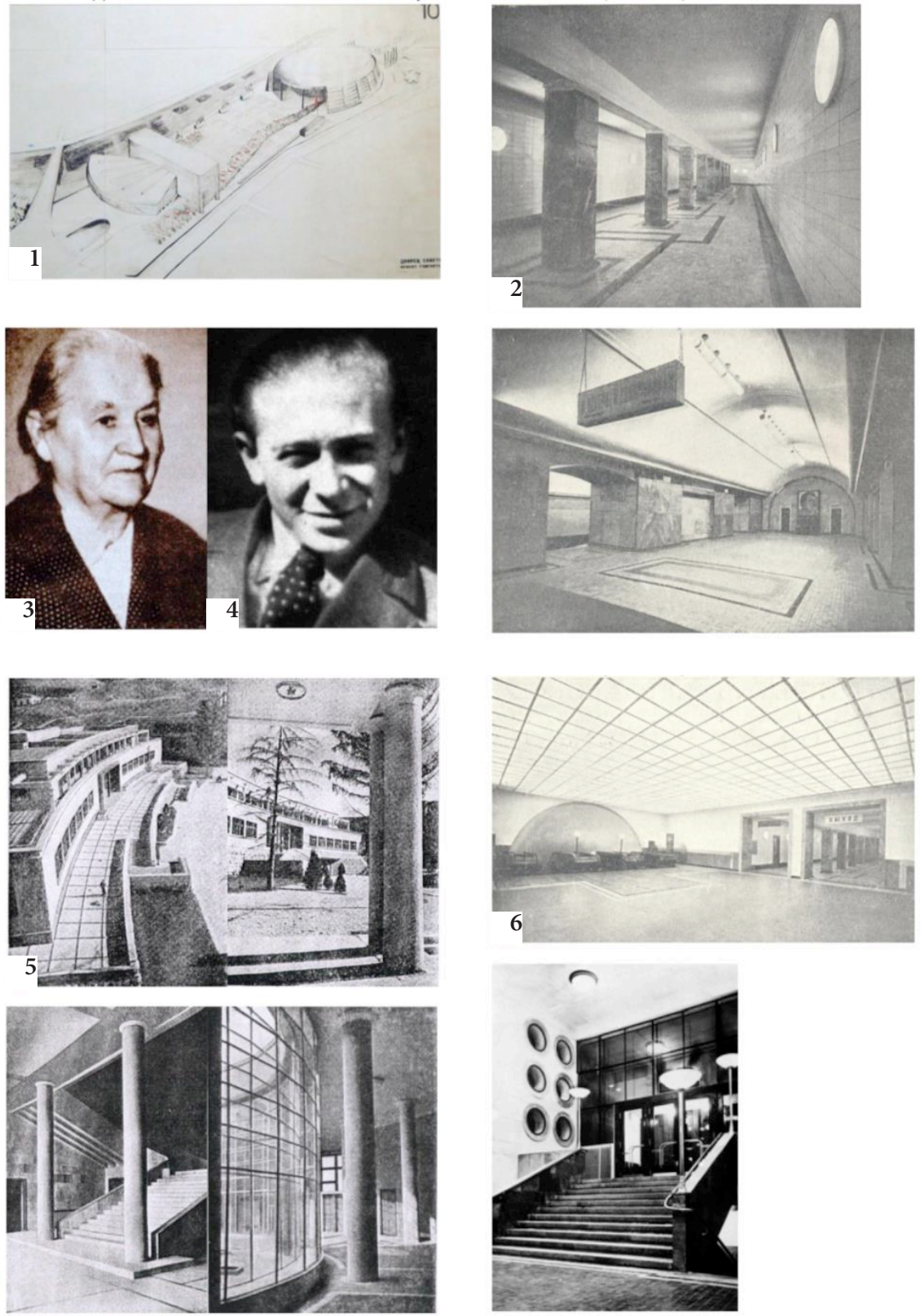